Int. J. Electrochem. Sci., 11 (2016) 2909 - 2918

\title{
Performance and Impedance Spectroscopy of co-Sensitization of Anthocyanin Dye And Semiconductor Quantum Dots in Sensitizing Solar Cells
}

\author{
H.K. Jun ${ }^{1, *}$, M.A. Careem $^{2}$ and A.K. Arof ${ }^{2}$ \\ ${ }^{1}$ Department of Mechanical and Material Engineering, Lee Kong Chian Faculty of Engineering \& \\ Science, Universiti Tunku Abdul Rahman, Sungai Long Campus, Bandar Sg. Long, 43000 Kajang, \\ Malaysia. \\ ${ }^{2}$ Centre for Ionics University of Malaya (CIUM), Department of Physics, University of Malaya, 50603 \\ Kuala Lumpur, Malaysia \\ *E-mail: junhk1@gmail.com
}

doi: 10.20964/110402909

Received: 7 December 2015 / Accepted: 2 February 2015 / Published: 1 March 2016

\begin{abstract}
In this work, anthocyanin dye was extracted in ethanol from black rice and used as a sensitizer together with $\mathrm{CdS}$ and $\mathrm{CdSe}$ quantum dots (QDs) in a QD-dye-co-sensitized $\mathrm{TiO}_{2}$ solar cell. QDs were prepared via wet solution processed method. Performances of the natural dye-sensitized solar cells with iodide based or cobalt based electrolyte were compared. Solar cells with cobalt-based electrolyte system showed stable performance throughout the measurement period. With the same cobalt based electrolyte, the solar cell co-sensitized with anthocyanin dye and both CdS and CdSe QDs showed the best performance. However, combination of anthocyanin dye and CdS QD as sensitizers showed an overall best performance with iodide-based electrolyte system. The low performance of the cells reported in this study can be attributed to the high recombination rate as observed from electrochemical impedance spectroscopy (EIS) studies.
\end{abstract}

Keywords: Anthocyanin, quantum dots, cobalt-based electrolyte, electrochemical impedance spectroscopy.

\section{$\underline{\text { FULL TEXT }}$}

(C) 2016 The Authors. Published by ESG (www.electrochemsci.org). This article is an open access article distributed under the terms and conditions of the Creative Commons Attribution license (http://creativecommons.org/licenses/by/4.0/). 